\title{
The Relative Performance of Different Types of Primary Schools in Bangladesh: A Multilevel Modeling Approach
}

\author{
L. N. Roy ${ }^{1}$, D. N. R. Paul ${ }^{2}$, U. K. Majumder ${ }^{3}$ \\ ${ }^{1}$ Principal, Dinajpur Laboratory School, and College, Balubari, Dinajpur Sadar, Dinajpur, Bangladesh \\ ${ }^{2}$ Department of Business Administration, Uttara University, Uttara, Dhaka, Bangladesh \\ ${ }^{3}$ Statistics Discipline, Khulna University, Khulna, Bangladesh \\ Email: ^lksminth@gmail.com,dnrpaul@gmail.com, majumderuk@yahoo.com
}

How to cite this paper: Roy, L. N., Paul, D. N. R., \& Majumder, U. K. (2020). The Relative Performance of Different Types of Primary Schools in Bangladesh: A Multilevel Modeling Approach. Creative Education, 11, 2354-2374.

https://doi.org/10.4236/ce.2020.1111173

Received: September 29, 2020

Accepted: November 21, 2020

Published: November 24, 2020

Copyright (C) 2020 by author(s) and Scientific Research Publishing Inc. This work is licensed under the Creative Commons Attribution-NonCommercial International License (CC BY-NC 4.0). http://creativecommons.org/licenses/by-nc/4.0/

\begin{abstract}
This study aims to compare the performance of public primary schools with private primary schools and ebtedayee madrasahs, and identify the significant predictors associated with school performance applying the multilevel model. Using the dataset collected (2015-2016) from 1230 fifth-grade students and 60 teachers of 60 primary schools of three different types (public, private, and madrasah) in the northern part of Bangladesh, we find that the performance of public primary schools is lower than that of private primary schools but higher than ebtedayee madrasahs. But after adjusting for student- and school-level predictors, the better effectiveness between public primary schools and private primary schools or public primary schools and ebtedayee madrasahs is disappeared. Finally, we find that the schools having optimum levels of teachers' belief, school academic atmosphere and learners' prior achievement, learning time; time needed to complete the homework, home academic atmosphere, self-educational expectation, and self-educational confidence are likely to achieve better performance. Recommendations are drawn to maintain the quality of primary education, one of the most important policy agendas, under the National Education Policy 2010 of Bangladesh or the policies of other countries that would ultimately enhance the probability of attaining the Sustainable Development Goal 4 (SDG 4).
\end{abstract}

\section{Keywords}

Multilevel Model, Madrasah, Public, Private, Primary School, Relative Performance 


\section{Introduction}

The introduction of a free and compulsory primary education for all children up to class-5 (1993), and "The Cash Support Stipend program" at public primary schools in Bangladesh (2002) had immediate positive impacts on the number of enrollment (87\% in 2005 and $97.7 \%$ in 2015, BANBEIS, 2016), school attendance, purchase of stationeries, and the reduction of student dropout (Directorate of Primary Education-DPE, Power and Participation Research Centre-PPRC, and UNICEF Bangladesh, 2013). As a result, the student-teacher ratio became high (46:1) that creates an ineffective learning environment (GoB, 2014). Some scholars also cited that the quality of education of public schools is compromised due to overloaded classrooms, fund reduction, and lack of teachers' motivation in some countries following the Universal Primary Education policy (Nishimura \& Ogawa, 2009; Oketch \& Somerset, 2010). The required fund was indeed a prerequisite for improving the learning environment but in Bangladesh, the allocation for the education sector was increased only $20.1 \%$, while the total budget was increased at an average rate of $28.7 \%$ from 2008 to 09 and 2012-13 (UNICEF, 2012).

Moreover, the quality of monitoring on the performance of teachers is very poor due to improper function of the internal monitoring system (Al Mamun, 2014). Therefore, some of the common characteristics of teacher-absenteeism, teachers' avoiding tendency, and lack of commitment to their works are found (Kremer et al., 2004; Wadhwa, 2009). Mentionable that, on average, the teacher absence rate of public primary schools in Bangladesh was 15.5\% during the survey period (Chaudhury et al., 2004). Due to the ineffectiveness of the public schools, to some extent, private schools were established rapidly in many developing countries (UNESCO, 2008) and rich parents moved to the schools of high scores where flexible management systems have existed (Rabbi, 2008). In the debate of public versus private schools, many scholars mentioned that private schools were superior to public schools because of having a better quality of education in private schools (Agarwal, 2000) and parents' dissatisfaction with public schools (NCES, 1997) and also some other reasons: more favorable disciplinary environment, stronger academic demands, disciplinary administration and teachers-parents involvement and a sense of community in private schools (Coleman \& Hoffer, 1987). On the other hand, the teachers of public schools are well trained, well experienced, and also well paid but their teaching quality is low that attracts parents to private schools (Retnakumar \& Arokiasamy, 2006).

The results of the latest study, "The National Student Assessment-2017" for Grades 3 and 5 in Bangladesh indicated that the performance of the private schools in all subjects of Grades 3 and 5 was the highest among different types of primary schools in 2015 and 2017 (GoB, 2018). Findings of a study mentioned that the mean scores in reading and mathematics of private school students were higher than those of public school students (Perie et al., 2005). Studies carried out by multilevel model revealed that there was no consistent or strong effect in 
favor of private schools after controlling for socioeconomic status and peer effects (Somers et al., 2004), and after adjusting for student-and school-level predictors confounded, the better effectiveness of the private schools disappeared and even reversed in most cases (Lubienski \& Lubienski, 2006). And the better performance of the private schools reversed in mathematics and disappeared in the reading of $4^{\text {th }}$ grade and for $8^{\text {th }}$ grade that remained the same in reading but disappeared in mathematics after adjusting for selected student-and school-level predictors (Braun et al., 2006).

Almost all parents indeed desire to admit their children into the highest performing type of primary schools especially, at the primary level. But in Bangladesh, it is observed that most of the parents are generally confused to decide what to do in selecting the right type of school for their children as they don't know the relative effectiveness of different types of primary schools (public, private, and madrasah) or the highest performing type of primary school. To get better assessment, this article investigates the two key research questions: 1) what are the relative performances of different types of primary schools, and 2) what factors impact on the school performance? School performance often means how well the students of a school perform their academic activities through the achievement of the test. As the educational dataset is hierarchically structured in nature (i.e. students nested in class and classes nested in school), the Multilevel model is the proper tool for analyzing this type of dataset (Goldstein, 2003) and for escaping the sampling bias and confounding effects (Lee \& Bowen, 2006). This study, therefore, using the multilevel modeling technique attempts to compare the public schools with private schools and madrasahs at the primary level and also identify the factors associated with school performance as no research work on this area is known to have been done by the same approach in Bangladesh.

The following attempted to present the review of some important literature wherein different methods and datasets were used to identify the predictors affecting academic performance scores.

\section{Literature Review}

\subsection{Student-Level Predictors}

Student achievement score was affected by parents' level of education and socioeconomic status (Sirin, 2005; Davis-Kean, 2005) and also the mother's educational level (OECD, 2009). Students coming from low SES backgrounds were more at-risk for their math performance (Coleman et al., 1966). The academic achievement was highly correlated with the combinations of two or more indicators of SES than any single indicator and also with the measures of the home atmosphere (White, 1982). The prior achievement was the powerful predictor for education expectations and consequently high educational attainment (Trusty, 2002) and played an important role than learning attitude or socioeconomic status (Ma \& Williams, 1999). The relationship between time spent on 
homework and students' academic performance was found to be a positive (Cooper, 1989; OECD, 2001) and a moderate at the school-level and a negative at the student-level (Trautwein, 2007). On the other hand, students who worked more than one hour each day performed slightly lower on average compared to the students spending time on math homework every day (Rodriguez, 2004). The opportunity to learn could help increase student learning and improve teaching (Muthen et al., 1995). A significant relationship was found between allocated to learning time \& reading scores, allocated to learning time \& mathematics test scores (Brown \& Saks, 1986) and the students' attitude toward learning and math achievement (Beaton et al., 1996; Abu-Hilal, 2000). The factor consisting of aspiration, self-confidence, and the value placed on math showed more important for achievement compared to the student background factors (Chepete, 2008). A strong positive relationship was found between self-confidence in learning math and math achievement for the students of Norway and Canada but not for the students of the United States (Ercikan et al., 2005; House, 2006).

\subsection{School-Level Predictors}

The result of a study indicated that student performance was not significantly affected by the level of teacher's education in $8^{\text {th }}$-grade (Wenglinsky, 2002). Though the senior teachers were considered more effective in their performance than compared to the junior teachers but about after 5 years of teaching experience the benefits of senior teachers appeared to be equal to the junior teachers (Darling Hammond, 2000). But another study mentioned there was a positive relationship between years of teaching and student performance (Fetler, 2001). The impact of subject matter knowledge in mathematics on student performance was found to be very weak (Darling-Hammond, 2000) and the effect of teacher's training on the performance scores was found insignificant (Mandeville \& Liu, 1997). Student achievement was positively influenced by the amount of time spent on subject content (Bodovski \& Farkas, 2007). There was an association between teachers' beliefs and achievement scores (Wilson \& Cooney, 2002) but conflicting results were found regarding teachers' belief and mathematics teaching practices (Raymond, 1997). The significant impact of instructional activity inside the classroom on the student performance scores was found (Yair, 2000; Lee et al., 2006). There was a strong relationship between the performance score and student-teacher interactions and emotional engagement in the classroom (Skinner \& Belmont, 1993). The study using the TIMSS 1995 Population 1 (9-year-olds) data for Japan mentioned more cooperative activity (i.e. work as pairs/small groups of learners) within the classroom especially for science subjects significantly affected the academic performance (House, 2006). It was found that student performance was significantly correlated with the school location (Mandeville \& Liu, 1997) and the student performance varied significantly by the change of the school location (Ministry of Education, 2005). Findings 
of a study revealed that student performance was affected by the school-level predictors: school-locality, the academic atmosphere at school perceived by the students, teachers, and principal (Chepete, 2008). The effect of class size on achievement scores was very little (Pong \& Pallas, 2001) and that was positive for small class size (Smith et al., 2003).

\section{Materials and Methods}

\subsection{Study Design}

\subsubsection{Data Collection Method}

The population of this research includes $5^{\text {th }}$-grade students of selected primary schools namely public, private, and madrasah (Islam religion-based educational institution) in the northern division of Bangladesh. Using a two-stage cluster sampling scheme, the required data were collected. In the first stage, 10 Upazilas were selected randomly from the list of all Upazilas of 8 districts in the Rangpur Division, the northern part of Bangladesh. In the second stage, a representative number of schools (60) under different locations (urban, suburban, and rural) were selected from each selected Upazila with a probability proportional to size (PPS) method. Finally, from each selected school, a complete enumeration of $5^{\text {th }}$-graders was done and relevant information was collected from both student-and school-level. The enumerated total number of $5^{\text {th }}$-grade students from 60 primary schools of different categories being present on the surveyed day was 1230.

\subsubsection{Data Collection Instrument}

Data had been collected through direct interviews of the $5^{\text {th }}$-grade students and a teacher from each selected school (involving in teaching at $5^{\text {th }}$-grade) using a pre-tested structured questionnaire designed for both open and closed-ended questions. The researcher himself and three field enumerators were involved in collecting data from the students and teachers.

\section{Variables}

Student-and school-level variables with their description and coding were shown in Table 1 and Table 2 separately attached to Appendix A. Based on the literature, student-and school-level predictors were selected for analyzing the data with the help of the SPSS Version 16.0:

Student-Level: prior achievement in class-4, time spent in learning with after school, the time needed to complete the homework, education of father, the academic atmosphere at home, self-educational expectation, and self-educational confidence.

Outcome Variable-Primary Education Completion Exam score in GPAs is a continuous dependent variable.

School-Level: school-type, teacher's belief, required time for homework, school location, and academic atmosphere at school perceived by the students, and perceived by the teachers. 


\subsubsection{Data Analysis Technique}

Descriptive Statistics includes computation of summary measures: means, standard deviations, proportions, etc.

Multilevel Models (MLMs) are the extension of the multiple regression models used for analyzing hierarchically structured data. As the students (level-1) clustered within the school (level-2), a 2-level multilevel model is applied for analyzing the dataset of the scores in GPAs. The general multiple linear regression models:

For Student-Level,

$$
Y_{i j}=\beta_{0 j}+\beta_{1 j} X_{1 i j}+\beta_{2 j} X_{2 i j}+\cdots+\beta_{p j} X_{p i j}+e_{i j}
$$

where, $i$ identifies students, $j$ identifies schools, and $p$ identifies variables for level-1, $Y_{i j}=$ outcome variable for student $i$ in school $j$;

$\beta_{0 j}=$ mean score for school $j$, adjusted for $X ; \beta_{p j}=$ student-level regression coefficients $(p=1,2, \cdots, P)$,

$X_{p i j}=$ student-level predictors $(p=1,2, \cdots, P)$, and $e_{i j}=$ student-level error term and assume that $e_{i j} \sim N\left(0, \sigma_{e}^{2}\right)$.

For School-Level, in the multilevel model with fixed slopes, the regression intercept $\left(\beta_{0 j}\right)$ of student-level was assumed to vary across the schools, but the regression slopes $\left(\beta_{p j}, \quad p=1,2, \cdots, P\right)$ of student-level predictors were assumed to be fixed for all schools.

Thus,

$$
\begin{gathered}
\beta_{0 j}=\gamma_{00}+\left[\gamma_{01(1)} Z_{1(1) j}+\gamma_{01(2)} Z_{1(2) j}\right]+\gamma_{02} Z_{2 j}+\cdots+\gamma_{0 Q} Z_{Q j}+u_{0 j} \\
\beta_{1 j}=\gamma_{10} ; \beta_{2 j}=\gamma_{20} ; \cdots ; \beta_{p j}=\gamma_{p 0}
\end{gathered}
$$

$Z_{1(1) j}=$ school-type indicator for school $j$, taking value 1 for private schools and 0 for other schools;

$Z_{1(2) j}=$ school-type indicator for school $j$, taking value 1 for ebtedayee madrashas and 0 for other schools;

$Z_{q j}=$ school-level variables $(q=2,3, \cdots, Q) ; \gamma_{00}=$ intercept for the regression of the adjusted school mean;

$\gamma_{01(1)} \& \gamma_{01(2)}=$ regression coefficients associated with $Z_{1(1)}$ and $Z_{1(2) j}$ representing the differences between the means of private \& public schools, and madrasahs \& public schools respectively; $\gamma_{0 q}=$ regression coefficients associated with school-level variables relative to student-level coefficients $(q=2,3, \cdots, Q)$; $\gamma_{p 0}=$ constant values of student-level regression coefficients $\left(\beta_{p j}, \quad p=1,2, \cdots, P\right)$ and $u_{0 j}=$ school-level error term following normal distribution with mean, 0 and $\operatorname{var}\left(u_{0 j}\right)=\sigma_{u 0}^{2}$.

For the Combined Level, The model is expressed as

$$
\begin{aligned}
Y_{i j}= & \left(\gamma_{00}+\gamma_{10} X_{1 i j}+\gamma_{20} X_{2 i j}+\cdots+\gamma_{p 0} X_{p i j}\right) \\
& +\left(\gamma_{01(1)} Z_{1(1) j}+\gamma_{01(2)} Z_{1(2) j}+\gamma_{02} Z_{2 j}+\cdots+\gamma_{0 Q} Z_{Q j}\right)+\left(u_{0 j}+e_{i j}\right)
\end{aligned}
$$

The variables $X$ and $Z$ can be modeled in their original, untransformed metric or can be centered (about respective grand means, or $X$ about respective group 
means) (Sullivan et al., 1999). This study used the maximum likelihood estimation method to estimate the parameters.

\subsection{Multilevel Model Specification}

Model 1: The intercept-only multilevel model having no predictors permitting us to ensure the existence of the school effects on the scores: $Y_{i j}=\gamma_{00}+u_{0 j}+e_{i j}$; $i=1,2, \cdots, 1230$ and $j=1,2, \cdots, 60$.

Model 2: Entering only "school-type" indicator into Model 1, the model is expressed as

$$
Y_{i j}=\gamma_{00}+\left[\gamma_{01(1)} Z_{1(1) j}+\gamma_{01(2)} Z_{1(2) j}\right]+u_{0 j}+e_{i j},
$$

Model3: Adding student-level predictors to Model 2, the model is expressed as

$$
\begin{aligned}
Y_{i j}= & \left(\gamma_{00}+\gamma_{10} X_{1 i j}+\gamma_{20} X_{2 i j}+\cdots+\gamma_{p 0} X_{p i j}\right) \\
& +\left[\gamma_{01(1)} Z_{1(1) j}+\gamma_{01(2)} Z_{1(2) j}\right]+\left(u_{0 j}+e_{i j}\right)
\end{aligned}
$$

Model 4: Adding school-level predictors to Model 3, the model is expressed as

$$
\begin{aligned}
Y_{i j}= & \left(\gamma_{00}+\gamma_{10} X_{1 i j}+\gamma_{20} X_{2 i j}+\cdots+\gamma_{p 0} X_{p i j}\right) \\
& +\left(\gamma_{01(1)} Z_{1(1) j}+\gamma_{01(2)} Z_{1(2) j}+\gamma_{02} Z_{2 j}+\cdots+\gamma_{0 Q} Z_{Q j}\right)+\left(u_{0 j}+e_{i j}\right)
\end{aligned}
$$

In each case, the associated variables are tested by the t-test and changes of variance in both levels are observed.

\subsection{Hypothesis and Test Statistic}

School academic performance indicates the average performance of the students of that school. The t-statistic was used to test the hypothesis:

1) School academic performance is the same across the school types and

2) Student-and school-level predictors are associated with school academic performance scores.

\section{Results and Discussions}

\subsection{School-Type Comparison Using Descriptive Statistics}

The number of different types of primary schools, the number of students, the average score of each type of primary school (GPAs), and the value of the test statistics are presented in Table 1.

The mean score of GPA of the $5^{\text {th }}$-grade students of public primary schools (3.87) was lower than that of private primary schools (4.59) but higher than ebtedayee madrasah (3.21) indicating that the academic performance of the private primary schools is the highest among different types of primary schools.

From Table 2, the average value of learning time and the required time to complete the homework for private schools were higher than those of the other two types of schools. The average achievement score for the students of grade- 5 varied with the school type: highest for private school and lowest for Ebtedayee Madrasha. This could be due to the fact students of private schools spend more 
Table 1. PEC Exam scores in GPA-2015 for each type of schools and value of the test statistics.

\begin{tabular}{|c|c|c|c|c|}
\hline School-type & $\begin{array}{l}\text { No. of } \\
\text { school } \\
(n=60)\end{array}$ & $\begin{array}{c}\text { No. of } \\
\text { student } \\
(\mathrm{n}=1230)\end{array}$ & $\begin{array}{c}\text { Mean } \\
\text { score } \\
(\mathrm{GPA}) \pm \mathrm{SE}\end{array}$ & $\begin{array}{c}\text { Value of Test } \\
\text { statistics } \\
\text { (Test of equality of mean) }\end{array}$ \\
\hline 1. Public & 29 & 682 & $3.87 \pm 0.04$ & $\mathrm{~F}=153.82$ \\
\hline 2. Private & 16 & 312 & $4.59 \pm 0.04$ & $p$-value $=0.000$ \\
\hline 3. Ebtedayee Madrasah & 15 & 236 & $3.21 \pm 0.07$ & \\
\hline 1. Public & 29 & 682 & $3.87 \pm 0.04$ & $\mathrm{t}=-11.81$ \\
\hline 2. Private & 16 & 312 & $4.59 \pm 0.04$ & $p$-value $=0.000$ \\
\hline 1. Public & 29 & 682 & $3.87 \pm 0.04$ & $\mathrm{t}=9.01$ \\
\hline 3. Ebtedayee Madrasha & 15 & 236 & $3.21 \pm 0.07$ & $p$-value $=0.000$ \\
\hline
\end{tabular}

Table 2. Student academic characteristics for each type of schools.

\begin{tabular}{lccc}
\hline \multicolumn{4}{c}{ School-type } \\
\multicolumn{1}{c}{ Predictor } & Public & Private & Madrasah \\
\hline 1. PEC Exam score in grade-5 (mean \pm SE) & $3.87 \pm 0.04$ & $4.59 \pm 0.04$ & $3.21 \pm 0.07$ \\
2. Prior achievement in grade-4 (mean \pm SE) & $3.17 \pm 0.04$ & $4.04 \pm 0.05$ & $2.49 \pm 0.06$ \\
3. Prior achievement in grade-3 (mean \pm SE) & $2.89 \pm 0.04$ & $3.83 \pm 0.06$ & $2.24 \pm 0.06$ \\
4. Learning time including after school (hrs.) (mean \pm SE) & $7.81 \pm 0.03$ & $8.61 \pm 0.04$ & $7.33 \pm 0.04$ \\
5. Time needed to complete the homework (hrs.) (mean \pm SE) & $1.93 \pm 0.03$ & $2.53 \pm 0.03$ & $1.48 \pm 0.04$
\end{tabular}

time learning and that their workload is indicated by more time to complete their homework compared to those for Madrasha and public school. In all cases, the performance level of the students increased: highest for grade- 5 students and lowest for grade- 3 students. Thus, the performance of a student in the lower class appears to be a good indicator of performance in the next classes.

Clearly, a large number of private school students expressed a more positive attitude toward higher education and better performance through the self-educational expectation (86\%) and self-educational confidence (73\%) than the students of public primary school and ebtedaeyee madrasah (Table 3). Thus, the predictors of student behavioral attitude factors might be thought of as the background causes for the academic performance of private school compared to the public primary school and ebtedayee madrasah. The result showed that a father with a higher level of education is more likely to choose a private school compared to the other two types of schools. Father's education level appeared to be an indicator of whether his children would be sent to a specific school type. Student's academic atmosphere at home is probably the most important family background factors for choosing a school type. The highest number of students (87\%) of private schools lived at home with a high academic atmosphere compared to the students of public schools (48\%) and edtedayee madrasah (28\%).

From Table 4, the students of the private schools used more time to finish 
Table 3. Student behavioral attitude and family background characteristics for each type of schools.

\begin{tabular}{|c|c|c|c|}
\hline \multirow{2}{*}{ Predictor } & \multicolumn{3}{|c|}{ School-type } \\
\hline & Public & Private & Madrasah \\
\hline \multicolumn{4}{|l|}{ 1. Self-educational expectation (\% of the student) } \\
\hline Don't know & 10 & 06 & 10 \\
\hline SSC, HSC, and Technical education & 41 & 08 & 63 \\
\hline First Degree, Master's Degree and above & 49 & 86 & 27 \\
\hline \multicolumn{4}{|l|}{ 2. Self-educational confidence (\% of the student) } \\
\hline Low confidence level & 31 & 08 & 59 \\
\hline Medium confidence level & 37 & 19 & 32 \\
\hline High confidence level & 32 & 73 & 09 \\
\hline \multicolumn{4}{|l|}{ 3. Education of father ( $\%$ of the father) } \\
\hline Illiterate & 16 & 04 & 10 \\
\hline School-level & 65 & 31 & 67 \\
\hline College and above level & 19 & 65 & 23 \\
\hline \multicolumn{4}{|c|}{ 4. The academic atmosphere at home (\% of the student) } \\
\hline The low academic atmosphere at home & 19 & 05 & 39 \\
\hline The medium academic atmosphere at home & 33 & 08 & 36 \\
\hline The high academic atmosphere at home & 48 & 87 & 25 \\
\hline
\end{tabular}

Table 4. School characteristics for each type of schools.

\begin{tabular}{lccc}
\hline \multicolumn{1}{c}{ Predictor } & \multicolumn{3}{c}{ School-type } \\
\cline { 2 - 4 } & Public & Private & Madrasah \\
\hline 1. Required time for homework (hrs.) & $2.50 \pm 0.02$ & $3.37 \pm 0.04$ & $2.07 \pm 0.02$ \\
(Mean \pm SE) & & & \\
2. Teacher's belief (\% of teacher) & 23 & 00 & 55 \\
Low teacher's belief & 49 & 50 & 42 \\
Medium teacher's belief & 28 & 50 & 03 \\
High teacher's belief & & & \\
3. School location (\% of school) & 18 & 57 & 55 \\
Urban & 32 & 37 & 24 \\
Sub-urban & 50 & 06 & 22 \\
Rural & & & \\
4. Academic atmosphere at school perceived & & & \\
by the students (\% of the student) & 17 & 05 & 39 \\
Low academic atmosphere at school & 31 & 08 & 36 \\
Medi. academic atmosphere at school & 52 & 87 & 25 \\
High academic atmosphere at school & & & \\
\hline
\end{tabular}

their homework. The average time required to complete the homework for pri- 
vate schools was the highest ( $3.37 \mathrm{hrs.)}$ followed by public primary school (2.50 hrs) and madrasah $(2.07 \mathrm{hrs}$.). It was found that $100 \%$ of private school teachers had medium to high belief concerning their job perception and responsibilities and other issues that may contribute to making the better academic performance of their students. About $95 \%$ of the students of private school reported the presence of a medium to the high academic atmosphere at their schools and the figure was $83 \%$ and $61 \%$ for public primary school and madrasah. The results seem to give a clear indication that the presence of a good academic atmosphere immensely necessary for better educational performance.

\subsection{School-Type Comparison Using Multilevel Models}

Different multilevel models were fitted to the data for comparing public primary schools with private primary schools \& madrasahs. For this, we need to compare the estimated parameters of the school-type indicators.

\section{Model 1 in Table 5}

The estimated intra-class correlation coefficient $(\rho=0.49)$ indicated that $49 \%$ of the total variation in the scores was found due to the differences between schools and $51 \%$ due to the differences within the school. The amount of variation in scores due to within school difference is more compared to between-school

Table 5. Estimates (and SE) of the successive model parameters.

\begin{tabular}{|c|c|c|c|c|}
\hline Model & Model 1 & Model 2 & Model 3 & Model 4 \\
\hline Fixed part & ${ }^{1}$ Estimate (SE) & ${ }^{1}$ Estimate (SE) & ${ }^{1}$ Estimate (SE) & ${ }^{1}$ Estimate (SE) \\
\hline Intercept & $3.87^{\star * \star}(0.10)$ & $3.85^{\star \star \star}(0.10)$ & $-1.58^{\star * *}(0.19)$ & $-1.53^{* * *}(0.20)$ \\
\hline \multicolumn{5}{|l|}{ Student-Level Predictor } \\
\hline Final result in class- 4 & & & $0.11^{* * *}(0.01)$ & $0.10^{\star * \star}(0.01)$ \\
\hline Time spent in learning & & & $0.44^{\star * \star}(0.03)$ & $0.43^{* * *}(0.03)$ \\
\hline $\begin{array}{c}\text { Time needed to complete } \\
\text { homework }\end{array}$ & & & $0.53^{\star * *}(0.03)$ & $0.52^{\star * \star}(0.03)$ \\
\hline $\begin{array}{l}\text { Father's education } \\
\text { (School-level) }\end{array}$ & & & $-0.01^{\mathrm{NS}}(0.02)$ & $-0.00^{\mathrm{NS}}(0.02)$ \\
\hline $\begin{array}{l}\text { Father's education } \\
\text { (College \& above) }\end{array}$ & & & $-0.03^{\mathrm{NS}}(0.03)$ & $-0.03^{\mathrm{NS}}(0.03)$ \\
\hline $\begin{array}{l}\text { Academic home atmosphere } \\
\text { (Medium) }\end{array}$ & & & $0.56^{* * *}(0.03)$ & $0.26^{* * *}(0.05)$ \\
\hline $\begin{array}{c}\text { Academic home atmosphere } \\
\text { (High) }\end{array}$ & & & $0.77^{\star * *}(0.05)$ & $0.43^{* * *}(0.06)$ \\
\hline $\begin{array}{l}\text { Student's self edu. expectation } \\
\text { (Medi.) }\end{array}$ & & & $0.25^{\star * *}(0.03)$ & $0.23^{* * *}(0.03)$ \\
\hline $\begin{array}{l}\text { Student's self edu. expectation } \\
\text { (High) }\end{array}$ & & & $0.07^{\star}(0.04)$ & $0.04^{\mathrm{NS}}(0.04)$ \\
\hline $\begin{array}{l}\text { Student's self edu. confidence } \\
\text { (Medi.) }\end{array}$ & & & $0.06^{*}(0.03)$ & $0.05^{\mathrm{NS}}(0.03)$ \\
\hline
\end{tabular}




\section{Continued}

\begin{tabular}{|c|c|c|c|c|}
\hline $\begin{array}{l}\text { Student's self edu. confidence } \\
\text { (High) }\end{array}$ & & & $-0.14^{\star \star}(0.05)$ & $-0.12^{* *}(0.05)$ \\
\hline \multicolumn{5}{|l|}{ School-Level Predictor } \\
\hline School type (Private) & & $0.60^{\star * \star}(0.17)$ & $-0.07^{\star \star}(0.03)$ & $-0.04^{\mathrm{NS}}(0.03)$ \\
\hline School type (Madrasah) & & $-0.61^{\star \star \star}(0.18)$ & $-0.04^{\mathrm{NS}}(0.03)$ & $-0.03^{\mathrm{NS}}(0.02)$ \\
\hline Teacher's belief (Medium) & & & & $0.06^{* \star}(0.02)$ \\
\hline Teacher's belief (High) & & & & $0.05^{\star}(0.03)$ \\
\hline School location urban & & & & $0.03^{\mathrm{NS}}(0.02)$ \\
\hline School location sub-urban & & & & $-0.02^{\mathrm{NS}}(0.02)$ \\
\hline Required time for homework & & & & $-0.04^{\star}(0.02)$ \\
\hline $\begin{array}{l}\text { School academic atmos. } \\
\text { (students) (Medi.) }\end{array}$ & & & & $0.36^{\star * \star}(0.05)$ \\
\hline $\begin{array}{l}\text { School academic atmos. } \\
\text { (students) (High) }\end{array}$ & & & & $0.42^{\star * *}(0.07)$ \\
\hline $\begin{array}{l}\text { School academic atmos. } \\
\text { (teachers) (Medi) }\end{array}$ & & & & $0.06^{* \star}(0.03)$ \\
\hline $\begin{array}{l}\text { School academic atmos. } \\
\text { (teachers) (High) }\end{array}$ & & & & $-0.00^{\mathrm{NS}}(0.04)$ \\
\hline Random part & ${ }^{2}$ Estimate & ${ }^{2}$ Estimate & ${ }^{2}$ Estimate & ${ }^{2}$ Estimate \\
\hline $\begin{array}{l}\text { Variance within } \\
\text { the school, } \sigma_{e}^{2}\end{array}$ & 0.56 & 0.56 & 0.06 & 0.060 \\
\hline $\begin{array}{l}\text { Intercept-variance } \\
\text { between schools, } \sigma_{u 0}^{2}\end{array}$ & 0.54 & 0.28 & 0.01 & 0.001 \\
\hline $\begin{array}{l}\text { Explained variance at } \\
\text { student-level, } R_{1}^{2}\end{array}$ & 0.00 & $0 \%$ & $89 \%$ & $89 \%$ \\
\hline $\begin{array}{l}\text { Explained variance at } \\
\text { school-level, } R_{2}^{2}\end{array}$ & 0.00 & $48 \%$ & $98 \%$ & $100 \%$ \\
\hline $\begin{array}{l}\text { Intra-class correlation } \\
\text { coefficient, } \rho \text { (ICC) }\end{array}$ & $49 \%$ & $33 \%$ & $14 \%$ & $02 \%$ \\
\hline Deviance $=-2$ Log-Likelihood & 2946 & 2919 & 42.41 & -36.83 \\
\hline
\end{tabular}

Notes: ${ }^{1}$ Estimate: Estimate of the coefficient; ${ }^{2}$ estimate: estimate of the variance-component; GPA-5: The highest GPA score at $5^{\text {th }}$ grade; SE: Standard Error; ( ): Std. Error; NS: Not significant; ${ }^{*}: p<0.10$; ${ }^{* *}: p<$ 0.05; ${ }^{* *}: p<0.01 . \rho(\mathrm{ICC})$ : Intra-class correlation coefficient $=\frac{\sigma_{u 0}^{2}}{\left(\sigma_{u 0}^{2}+\sigma_{e}^{2}\right)} \times 100$; Effect Size: Ratio of the absolute value of the estimate to the std. deviation of the scores (1.03); Model Comparison: In general, the model of a lower deviance $=-2 \log$ Likelihood fits better than the model of higher deviance. To test this, the required likelihood ratio test statistic, (LR) = difference of the deviances of the two models $\chi^{2}$-distribution with d.f. computed by the difference in the number of parameters of both models and Explained Variance: $R_{1}^{2}\left(\right.$ Model 2) $=\left(\frac{\sigma_{e \mid b}^{2}-\sigma_{e \mid m}^{2}}{\sigma_{e \mid b}^{2}}\right), \sigma_{e \mid b}^{2}$ and $\sigma_{e \mid m}^{2}$ are student-level residual variances for Model 1 \& comparison Model respectively. $R_{2}^{2}\left(\right.$ Model 2) $=\left(\frac{\sigma_{u \circ \mid b}^{2}-\sigma_{u|| m}^{2}}{\sigma_{u \circ \mid b}^{2}}\right), \quad \sigma_{u \circ \mid b}^{2} \& \quad \sigma_{u \mid m b}^{2}$ are school-level residual variance for Model 1 \& comparison Model (Raudenbush \& Bryk, 2002). Similarly, explained variances are also estimated for Model 3 and Model 4. 
differences. As $\rho>0.1$, the value of $\rho$ indicated the degree of dependence of the students' scores within the same school violating the OLS assumption (Rowan et al., 1991). Here multilevel models give more precise results compared to the multiple regression models.

\section{Model 2 in Table 5}

The two coefficients of private school (0.60) and ebtedayee madrasah $(-0.61)$ indicated that public schools' mean score was significantly 0.60 points lower than that of private schools with the effect size of 0.58 and 0.61 points higher compared to ebtedayee madrasah with the corresponding effect size of 0.59 respectively. Therefore, the performance of private primary schools is the best among different types of primary schools. This finding was supported by the previous research study (Perie et al., 2005; Lubienski \& Lubienski, 2006; Braun et al., 2006). The explained variance remained $0 \%$ at the student-level and $48 \%$ at the school-level (Figure 2) meaning that school-type variables can explain only the school-level variation.

\section{Model 3 in Table 5}

The difference between the mean scores of private and public schools $(-0.07)$ was found to be significant at a $5 \%$ level with an effect size of 0.07 but that of ebtedayee madrasahs and public schools $(-0.04)$ was insignificant. So, the performance of private schools slightly goes down ( 0.07 points) compared to public schools adjusting the student-level predictors, as supported by the prior study (Lubienski \& Lubienski, 2006; Braun et al., 2006). The better effectiveness of private schools becomes the opposite due to having more privileged students in private schools (Lubienski \& Lubienski, 2006: p. 30). Student-level predictors except for the education of father were significantly associated with the performance scores at a 5\% level. Students' achievement scores were positively affected by the prior achievement (Ma \& Williams, 1999; Trusty, 2002); time spent in learning (Brown \& Saks, 1986; Muthen et al., 1995), time needed to complete the homework (Cooper, 1989; OECD, 2001); the academic atmosphere at home (White, 1982) and student's self-educational expectation, and confidence (Ercikan et al., 2005; Chepete, 2008). 89\% of the variation (student-level) was explained by the student-level predictors and $98 \%$ (school-level) by the student-level and school-type indicators (Figure 2). Clearly, the student-level predictors can explain the variation at both student-and school-level. This statement is consistent with the prior study (Hox et al., 2010).

\section{Model 4 in Table 5}

Both of the coefficients of private school $(-0.03)$ and ebtedayee madrasah $(-0.01)$ were near about to zero and found to be insignificant at $5 \%$ level meaning that the estimated differences between the mean scores of private schools \& public schools and ebtedayee madrasahs \& public schools were unaffected and dissolved due to entering school characteristics into Model 3, as mentioned by the previous study (Lubienski \& Lubienski, 2006; Braun et al., 2006). Students' performance scores were significantly correlated (at 5\% level) with the teacher's belief (Wilson \& Cooney, 2002); required time for homework (Trautwein, 2007); 
the academic atmosphere at school perceived by the students, and by the teachers (Chepete, 2008) but not that with school location. The explained variance remained constant (89\%) at the student-level but increased from $98 \%$ to $100 \%$ at the school-level meaning that school-level predictors can explain only the school-level variation (2\%), a little amount (Figure 2). The student-level predictors, therefore, have a more predictive effect on scores compared to school-level predictors, as established by the earlier study (Hox et al., 2010).

In final Model 4, the best-fitted model obtained by likelihood ratio test, only $2 \%$ of the total variation was due to differences between schools and $98 \%$ due to differences within the school (Figure 3) meaning that the variation due to between-school differences reduced but the variation due to within-school difference increased. Therefore, within school difference is more accountable for the amount of variation in scores compared to between-school differences.

To support and analyze the results of Table 5, Figures 1-4 were drawn graphically by taking successive multilevel models on the $\mathrm{X}$-axis and school type difference, explained variation, intra-class correlation coefficient (ICC), and deviance on the $\mathrm{Y}$-axis respectively.

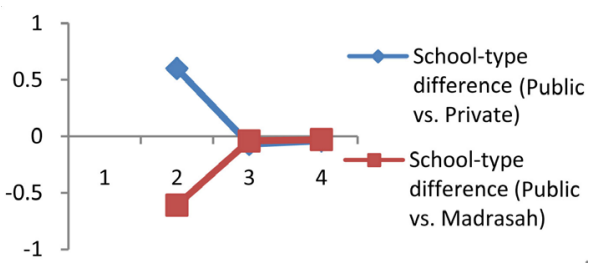

Figure 1. School-type differences for successive multilevel models.

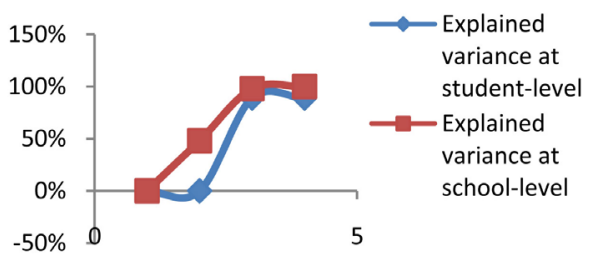

Figure 2. Explained variances (level-wise) of successive multilevel models.

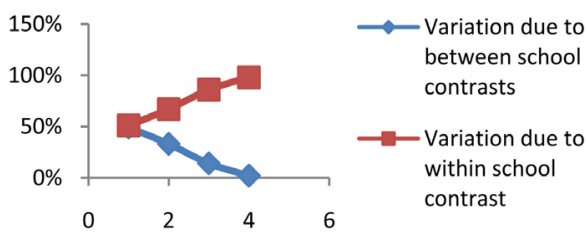

Figure 3. ICCs for successive multilevel models.

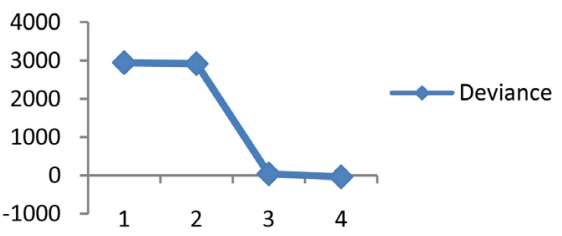

Figure 4. Deviances for successive multilevel models. 


\section{Limitations}

The performance of the comparison of three different types of primary schools (public, private, and madrasah) may be moderate due to the heterogeneous composition of each type of school. Though the multilevel model, an advanced statistical tool, has been applied to analyze the nested dataset, probable biasness may occur as the samples drawn especially from private schools and madrasahs are comparatively smaller in sizes. Most importantly, as the present study has been conducted based on the survey design, not on the experimental design, the data collection procedure has been completed within a fixed period of time. Consequently, it has not been possible to collect some specific type of information on the student characteristics such as academic achievement scores, between-school transfer, etc. at different time intervals. The conclusion, therefore, based on this study cannot absolutely be drawn that the effectiveness of any particular type of primary school is better compared to other types of primary schools (Lubienski \& Lubienski, 2006; Braun et al., 2006).

\section{Conclusion and Recommendations}

\subsection{Conclusion}

Within the limitations of this study, the major findings that have been spotlighted to reveal the relative effectiveness of different types of primary schools, as well as student and school context significant predictors influence on the school performance, are:

* Without adjusting for student- and school-level predictors, the academic performance of public primary schools is lower than that of private primary schools but higher than ebtedayee madrasahs. But after adjusting for the predictors of those two levels, the better effectiveness between public primary schools and private primary schools or public primary schools and ebtedayee madrasahs is disappeared.

* The academic performance of the primary schools is significantly affected by student-level predictors: prior achievement, time spent in learning with after school, time needed to complete the homework, student's self-educational expectation, and student's self-educational confidence and academic atmosphere at home and school-level predictors. teacher's belief, required time for homework, and academic atmosphere at school perceived by the students and teachers.

\subsection{Recommendations}

Different types of schools are in different formations but the desirable performance is indifferent to all. The most important guidelines that could play an effective role in the advancement of the school academic performance by minimizing two sources of variation in scores: "within-school variation" and "between-school variation" are:

Students should pay more attention to the optimal levels of their prior 
achievement, learning time including after school, required homework time, self-educational expectation, and self-educational confidence for their better academic performance and accordingly perform their studies. Parents and teachers, in this context, should simultaneously guide their learners and

* Both parents and school authority should improve their respective academic atmospheres and also the teachers' belief that may help motivate the students to be attentive more to their academic functions.

\section{Acknowledgements}

The authors are grateful for the support of the Higher Education Quality Enhancement Project (HEQEP CP3319), Bangladesh in this study. They are also grateful to all participating students and their teachers of selected primary schools under this study and the field enumerators.

\section{Notes on Contributors}

L. N. Roy focuses on determining the factors affecting students' academic performance using the multilevel modeling technique in his doctoral research. His research interest is in the area of application of multilevel modeling and recent publications are on school dropout causes and comparing the probable risk of dropout of a student. LN Roy designed the study, performed the statistical analysis, and wrote the draft of the manuscript.

D. N. R. Paul is a Full Professor at the Department of Business Administration at Uttara University, Uttara, Dhaka, Bangladesh. His research interest is in the area of statistical modeling, probability distribution, and agricultural experiments. He suggested the sampling design and made corrections in the manuscripts.

U. K. Majumder is a Full Professor at Statistics Discipline in Khulna University, Khulna, Bangladesh. His major research interests include educational research, social research, econometric models, and multilevel analysis. He contributed to the design of this research study and guided LN Roy for statistical analysis of data using a multilevel modeling technique.

\section{Conflicts of Interest}

No potential conflict of interest was reported by the authors.

\section{References}

Abu-Hilal, M. M. (2000). A Structural Model of Attitudes toward School Subjects, Academic Aspirations, and Achievement. Educational Psychology, 20, 75-84. https://doi.org/10.1080/014434100110399

Agarwal, Y. (2000). Public and Private Partnership in Primary Education in India: A Study of Unrecognized Schools in Haryana (p. 5). NIEPA (DISE).

Al Mamun, M. A. (2014). Assessing the Effectiveness of School Management Committees (SMCs) in Improving Governance of Primary Schools in Bangladesh: A Case Study of selectIve SMCs at Gouripur Upazila in Mymensingh District. Master's Dissertation, Dhaka: Institute of Governance Studies, BRAC University. 
BANBEIS (2016). Educational Structure of Bangladesh. Dhaka: Bangladesh Bureau of Educational Information and Statistics, Ministry of Education.

Beaton, A. E., Mullis, I. V. S., Martin, M. O., Gonzalez, E. J., Kelly, D. L., \& Smith, T. A. (1996). Mathematics Achievement in the Middle School Years: IEA's Third International Mathematics and Science Study (TIMSS). Chestnut Hill, MA: Boston College.

Bodovski, K., \& Farkas, G. (2007). Mathematics Growth in Early Elementary School: The Roles of Beginning Knowledge, Student Engagement, and Instruction. The Elementary School Journal, 108, 115-130. https://doi.org/10.1086/525550

Braun, H., Jenkins, F., \& Grigg, W. (2006). Comparing Private Schools and Public Schools Using Hierarchical Linear Modeling (NCES 2006-461). Washington DC: Department of Education, National Center for Education Statistics, Institute of Education Sciences Government Printing Office.

Brown, B. W., \& Saks, D. H. (1986). Measuring the Effects of Instructional Time on Student Learning: Evidence from the Beginning Teacher Evaluation Study. American Journal of Education, 94, 480-500. https://doi.org/10.1086/443863

Chaudhury, N., Hammer, J., Kremer, M., Mularidharan, K., \& Rogers, H. (2004). Roll Call: Teacher Absence in Bangladesh. World Bank, Unpublished.

Chepete, P. (2008). Modeling of the Factors Affecting Mathematical Achievement of Form 1 Students in Botswana Based on the 2003 Trends in International Mathematics and Science Study. Doctoral Dissertation, Bloomington, IN: Graduate Faculty, Indiana University. (Online Version)

Coleman, J. S., \& Hoffer, T. (1987). Public and Private High Schools: The Impact of Communities. New York: Basic Books.

Coleman, J. S., Campbell, E. Q., Hobson, C. J., McPartland, J., Mood, A. M., Weinfeld, F. D., \& Work, R. L. (1966). Equality of Educational Opportunity. Washington DC: U.S. Government Printing Office.

Cooper, H. M. (1989). Research on Teaching Monograph Series. Homework. New York: Longman. https://doi.org/10.1037/11578-000

Darling-Hammond, L. (2000). Teacher Quality and Student Achievement: A Review of State Policy Evidence. Educational Policy Analysis Archives, 8, 1-44. https://doi.org/10.14507/epaa.v8n1.2000

Davis-Kean, P. E. (2005). The Influence of Parent Education and Family Income on Child Achievement: The Indirect Role of Parental Expectations and the Home Environment. Journal of Family Psychology, 19, 294-304. https://doi.org/10.1037/0893-3200.19.2.294

Directorate of Primary Education-DPE, Power and Participation Research Centre-PPRC, and UNICEF Bangladesh (2013). Bangladesh Primary Education Stipends: A Qualitative Assessment.

Ercikan, K., McCreith, T., \& Lapointe, T. (2005). How Are Non-School Related Factors Associated with Participation and Achievement in Science? An Examination of Gender Differences in Canada, the USA, and Norway. In S. J. Howie, \& T. Plomp (Eds.), Contexts of Learning Mathematics and Science: Lessons Learned from TIMSS (pp. 211-225). Netherlands: Swets \& Zeitlinger International Publishers.

Fetler, M. (2001). Student Mathematics Achievement Test Scores, Dropout Rates, and Teacher Characteristics. Teacher Education Quarterly, 28, 151-168.

GoB (2014). Bangladesh Primary Education Annual Sector Performance Report-2014. Dhaka, Bangladesh: Monitoring and Evaluation Division, Directorate of Primary Education, Government of Bangladesh.

https://dpe.portal.gov.bd/sites/default/files/files/dpe.portal.gov.bd/publications/e59cle 
65 d871 446e a5f5 3ab69fee590b/Final\%20ASPR\%202014

GoB (2018). The National Student Assessment 2017 for Grades 3 and 5. Dhaka, Bangladesh: Monitoring and Evaluation Division, Directorate of Primary Education, Government of Bangladesh.

https://dpe.portal.gov.bd/sites/default/files/files/dpe.portal.gov.bd/publications/24ec04 b1 3064 41d3 9ac7 9b778a02e17b/The\%20National\%20Student\%20Assessment\%20 \%202017\%20Book\%20

Goldstein, H. (2003). Multilevel Statistical Models (3rd ed.). London: Edward Arnold.

House, J. D. (2006). The Effects of Classroom Instructional Strategies on Science Achievement of Elementary-School Students in Japan: Findings from the Third International Mathematics and Science Study (TIMSS). International Journal of Instructional Media, 33, 217-229.

Hox, J. J., Moerbeek, M., \& van de Schoot, R. (2010). Multilevel Analysis. Techniques and Applications, Quantitative Methodology Series (2nd ed.). New York: Routledge. https://doi.org/10.4324/9780203852279

Kremer, M., Chaudhury, N., Murlidharan, K., Rogers, F. H., \& Hammer, J. (2004). Teacher Absence in India: A Snapshot. Journal of the European Economic Association, 3, 658-667.

Lee, J. S., \& Bowen, N. K. (2006). Parent Involvement, Cultural Capital, and the Achievement Gap among Elementary School Children. American Educational Research Journal, 43, 193-218. https://doi.org/10.3102/00028312043002193

Lee, O., Deaktor, R. A., Hart, J. E., Cuevas, P., \& Enders, C. (2006). An Instructional Intervention's Impact on the Science and Literacy Achievement of Culturally and Linguistically Diverse Elementary Students. Journal of Research in Science Teaching, 42, 857-887. https://doi.org/10.1002/tea.20071

Lubienski, C., \& Lubienski, S. T. (2006). Charter, Private, Public Schools, and Academic Achievement: New Evidence from NAEP Mathematics Data. New York, NY: Columbia University.

Ma, X., \& Williams, J. D. (1999). Dropping Out of Advanced Mathematics: How Much Do Students and Schools Contribute to the Problem? Educational Evaluation and Policy Analysis, 21, 365-383. https://doi.org/10.3102/01623737021004365

Mandeville, G. K., \& Liu, Q. (1997). The Effect of Teacher Certification and Task Level on Mathematics Achievement. Teaching and Teacher Education, 13, 397-407. https://doi.org/10.1016/S0742-051X(96)00031-5

Martin, O. M. (2005). TIMSS 2003 User Guide for International Database. Boston, MA: TIMSS \& PIRLS International Study Center.

Ministry of Education (2005). Report on the Trends in International Mathematics and Science Study (TIMSS) Project for 2003. Gaborone, Botswana: Government Publishers.

Muthen, B., Huang, L., Jo, B., Khoo, S., Goff, G. N., Novak, J. R., \& Shih, J. C. (1995). Opportunity-to-Learn Effects on Achievement: Analytical Aspects. Educational Evaluation and Policy Analysis, 17, 371-403. https://doi.org/10.3102/01623737017003371

NCES, National Centre for Educational Statistics (1997). Public and Private Schools: How Do They Differ? NCES 97-983, U.S. Department of Education.

Nishimura, M., \& Ogawa, K. (2009). Universal Primary Education Policy in Sub-Saharan Africa: A Comparative Analysis of Ghana, Kenya, Malawi, and Uganda and Policy Recommendations. Kobe, Japan: Kobe University.

OECD (Organization for Economic Co-operation and Development) (2009). PISA 2006 Technical Report. Paris: OECD Publishing. 
OECD (Organization for Economic Co-operation and Development) (2001). Knowledge and Skills for Life: First Results from the OECD Program for International Student Assessment. Paris: OECD Publishing.

Oketch, M., \& Somerset, A. (2010). Free Primary Education and after in Kenya: Enrolment Impact, Quality Effects, and the Transition to Secondary School. Create Pathways to Access Research Monographs (Vol. 37). Sussex, UK: Consortium for Research on Educational Access, Transition \& Equity.

Perie, M., Vanneman, A., \& Goldstein, A. (2005). Student Achievement in Private Schools: Results from NAEP 2000-2005 (NCES No. 2006459). Washington DC: National Center for Education Statistics.

Pong, S., \& Pallas, A. (2001). Class Size and Eighth-Grade Math Achievement in the United States and Abroad. Educational Evaluation \& Policy Analysis, 23, 251-273. https://doi.org/10.3102/01623737023003251

Rabbi, A. F. M. (2008). Primary Education in Bangladesh: Viability of Millennium Development Goals. Doctoral Dissertation, Dhaka: BRAC University.

Raudenbush, S. W., \& Bryk, A. S. (2002). Hierarchical Linear Models: Applications and Data Analysis Methods. Newbury Park, CA: Sage Publications.

Raymond, A. M. (1997). Inconsistency between a Beginning Elementary School Teacher's Mathematics Beliefs and Teaching Practice. Journal for Research in Mathematics Education, 28, 550-576. https://doi.org/10.2307/749691

Retnakumar, J. N., \& Arokiasamy, P. (2006). Explaining School Enrolment Trends in Kerala. Journal of South Asian Development, 1, 232-248. https://doi.org/10.1177/097317410600100204

Rodriguez, M. C. (2004). The Role of Classroom Assessment in Student Performance on TIMSS. Applied Measurement in Education, 17, 1-24. https://doi.org/10.1207/s15324818ame1701 1

Rowan, B., Raudenbush, W. S., \& Kang, S. J. (1991). Organizational Design in High Schools: A Multilevel Analysis. American Journal of Education, 99, 238-266. https://doi.org/10.1086/443980

Sirin, S. R. (2005). Socioeconomic Status and Academic Achievement: A Meta-Analytic Review of Research. Review of Educational Research, 75, 417-453. https://doi.org/10.3102/00346543075003417

Skinner, E. A., \& Belmont, M. J. (1993). Motivation in the Classroom: Reciprocal Effects of Teacher Behavior and Student Engagement across the School Year. Journal of Educational Psychology, 85, 571-581. https://doi.org/10.1037/0022-0663.85.4.571

Smith, P., Molnar, A., \& Zohorik, J. (2003). Class-Size Reduction in Wisconsin: A Fresh Look at the Data. Educational Leadership, 61, 72-74.

Somers, M. A., McEwan, P. J., \& Willms, J. D. (2004). How Effective Are Private Schools in Latin America? Comparative Education Review, 48, 48-69.

https://doi.org/10.1086/379841

SPSS Version 16.0. Student Version for Windows, Inc. SPSS.

Sullivan, L. M., Dukes, K. A., \& Losina, E. (1999). Tutorial in Biostatistics: An Introduction to Hierarchical Linear Modeling. Statistics in Medicine, 18, 855-888. https://doi.org/10.1002/(SICI)1097-0258(19990415)18:7<855::AID-SIM117>3.0.CO;2-7

Trautwein, U. (2007). The Homework-Achievement Relation Reconsidered: Differentiating Homework Time, Homework Frequency, and Homework Effort. Learning and Instruction, 17, 372-388. https://doi.org/10.1016/j.learninstruc.2007.02.009

Trusty, J. (2002). African Americans' Educational Expectations: Longitudinal Causal 
Models for Women and Men. Journal of Counseling and Development, 80, 332-345. https://doi.org/10.1002/j.1556-6678.2002.tb00198.x

UNESCO (2008). Education for All Global Monitoring Report 2009. Paris: UNESCO.

UNICEF (2012). Children and Education Budget in Bangladesh. New York: UNICEF.

Wadhwa, W. (2009). Are Private Schools Performing Better than Government Schools? Annual Status of Education Report (Rural), New Delhi.

Wenglinsky, H. (2002). How Schools Matter: The Link between Teacher Classroom Practices and Student Academic Performance. Education Policy Analysis Archives, 10, 1-30. https://doi.org/10.14507/epaa.v10n12.2002

White, K. R. (1982). The Relation between Socioeconomic Status and Academic Achievement. Psychological Bulletin, 91, 461-481. https://doi.org/10.1037/0033-2909.91.3.461

Wilson, M. S., \& Cooney, T. (2002). Mathematics Teacher Change and Development. In G. C. Leder, E. Pehkonen, \& G. Torner (Eds.), Beliefs: A Hidden Variable in Mathematics Education? (pp. 127-147). Boston, MA: Kluwer Academic Publishers.

Yair, G. (2000). Not Just about Time: Instructional Practices and Productive Time in School. Educational Administration Quarterly, 36, 485-512.

https://doi.org/10.1177/00131610021969083 


\section{Appendix A}

Table A1. Student-level variables with their description and coding.

\begin{tabular}{|c|c|c|}
\hline Variable & Variable description & Code \\
\hline Sex & Single-item variable indicating the sex of the student. & $1=$ Boy, $2=$ Girl \\
\hline $\begin{array}{l}\text { Academic achievement } \\
\text { (Outcome variable) }\end{array}$ & Single-item variable indicating the PECE result in GPAs. & Continuous variable ranged from 0.00 to 5.00 \\
\hline Prior achievement- 4 & $\begin{array}{l}\text { Single-item variable indicating the result of the final } \\
\text { exam in class } 4 .\end{array}$ & Continuous variable ranged from 0.00 to 5.00 \\
\hline Prior achievement- 3 & $\begin{array}{l}\text { Single-item variable indicating the result of the final } \\
\text { exam in class } 3 \text {. }\end{array}$ & Continuous variable ranged from 0.00 to 5.00 \\
\hline Father education & $\begin{array}{l}\text { Single-item variable indicating the level of education } \\
\text { of the father. }\end{array}$ & $\begin{array}{l}1=\text { illiterate }, 2=\text { primary } \\
3=\text { SSC, } 4=\text { HSC, } 5=\text { honors } \\
6=\text { masters and above }\end{array}$ \\
\hline Mother education & $\begin{array}{l}\text { Single-item variable indicating the level of education } \\
\text { of the mother. }\end{array}$ & $\begin{array}{l}1=\text { illiterate } 2=\text { primary, } \\
3=\text { SSC, } 4=\text { HSC, } 5=\text { honors, } \\
6=\text { masters and above }\end{array}$ \\
\hline Time spent in learning & Single-item variable indicating total learning time in hour. & Continuous variable ranged from 2 to 16 hours \\
\hline Needed homework time & $\begin{array}{l}\text { Single-item variable indicating needed homework time } \\
\text { in hour. }\end{array}$ & Continuous variable ranged from 0.50 to 7 hours \\
\hline $\begin{array}{l}\text { The academic } \\
\text { atmosphere at school } \\
\text { (perceived by the student) } \\
\text { (School-level variable) }\end{array}$ & $\begin{array}{l}\text { Composite variable based on } \\
\text { how much does the student } \\
\text { agree with the following } \\
\text { statements: } \\
\text { 1) Feel secured and } \\
\text { comfortable at school, } \\
\text { 2) Get interested in the classroom, } \\
\text { 3) Teachers teach in a } \\
\text { worm-class room environment, } \\
\text { 4) Feel comfortable asking questions in class, } \\
\text { 5) Teachers' behavior are cooperative, and } \\
\text { 6) Teachers encourage me to study in the classroom. }\end{array}$ & $\begin{array}{l}\text { Initial code } \\
\text { (five-point Likert Scale): } \\
1=\text { never, } 2=\text { rare, } 3=\text { sometimes, } \\
4=\text { maximum times, } 5=\text { always; } \\
\text { Recode for composite variable: } \\
1=\text { Low academic atmosphere at school } \\
\text { if average point } \leq 2 \text {, } \\
2=\text { Medium academic atmosphere } \\
\text { if } 2<\text { average } \\
\text { point }<4 \text {; } \\
3=\text { High academic atmosphere at school, } \\
\text { if average point } \geq 4 . \\
\text { [c/f TIMSS User guide Martin (2005)] }\end{array}$ \\
\hline $\begin{array}{l}\text { Academic } \\
\text { atmosphere } \\
\text { at home }\end{array}$ & $\begin{array}{l}\text { Composite variable based on how much does the student } \\
\text { agree with the following statements: } \\
\text { 1) Academic atmosphere is nice at home, } \\
\text { 2) Parents provide me all items of my choice, } \\
\text { 3) Parents help me with all of my homework, } \\
\text { 4) Parents always inspire me to study something, }\end{array}$ & $\begin{array}{l}\text { Initial code } \\
\text { (five-point Likert Scale): } \\
1=\text { never, } 2=\text { rare, } \\
3=\text { sometimes, } \\
4=\text { maximum times, } 5 \text { = always; } \\
\text { Recode for composite variable: } \\
1=\text { Low academic atmosphere, } \\
\text { if average point } \leq 2 \text {, } \\
2=\text { Medium academic atmosphere, } \\
\text { if } 2<\text { average } \\
\text { point }<4 \text { and } 3=\text { High academic atmosphere, } \\
\text { if average point } \geq 4 \text {. }\end{array}$ \\
\hline $\begin{array}{l}\text { Student's } \\
\text { self-educational } \\
\text { expectation }\end{array}$ & $\begin{array}{l}\text { Single-item indicator variable based on how far at school } \\
\text { does the student expect to go: }\end{array}$ & $\begin{array}{l}1=\text { SSC } \\
2=\text { HSC } \\
3=\text { Technical Education, } \\
4=\text { First Degree, } \\
5=\text { Master's Degree and above, } \\
6=\text { Don't know. }\end{array}$ \\
\hline
\end{tabular}




\section{Continued}

Student's self-educationa confidence
Composite variable based on how much does the student agree with the following statements:

1) Enjoy learning in all subjects,

2) Learn quickly any subject,

3) Earn a good grade in all subjects.
Original code:

$1=$ Yes, 2 = No

Recode for composite variable:

3 = High confidence level,

if coded 1 in exact 3 statements,

2 = Medium confi. level,

if coded 1 in exact 2 statements

1 = Low confidence level,

if coded 1 in exact 1 statement.

Table A2. School-level variables with their description and coding.

\begin{tabular}{|c|c|c|}
\hline Variable & Variable description & Code \\
\hline Sex & Single-item variable indicating the sex of the teacher. & $\begin{array}{l}1=\text { Male } \\
2=\text { Female }\end{array}$ \\
\hline School type & Single-item variable indicating the type of school & $\begin{array}{l}1=\text { Public } \\
2=\text { Private } \\
3=\text { Ebtedayee Madrasha }\end{array}$ \\
\hline $\begin{array}{l}\text { Needed } \\
\text { homework time }\end{array}$ & $\begin{array}{l}\text { Single-item variable indicating time students should spend } \\
\text { for homework in hour. }\end{array}$ & $\begin{array}{l}\text { Variable (continuous) } \\
\text { ranged from } 2 \text { to } 8 \text { hours. }\end{array}$ \\
\hline Teacher's belief & $\begin{array}{l}\text { Composite variable based on how much the teacher agrees } \\
\text { with the following statements: } \\
\text { 1) All in all, I am satisfied with my job, } \\
\text { 2) I feel I am making an important academic contribution to } \\
\text { the lives of my students, } \\
\text { 3) I try hard to make the progress of the students who are } \\
\text { most disobedient and disinterested in, } \\
\text { 4) I'm successful to teach the students in the classroom, } \\
\text { 5) I know how to get through to the students and } \\
\text { 6) In the local community, teachers are well respected. }\end{array}$ & $\begin{array}{l}\text { Initial code } \\
\text { (five-point Likert Scale): } \\
1=\text { disagree a lot, } 2=\text { disagree a little, } \\
3 \text { = medium, } 4=\text { agree a little, } 5=\text { agree a lot } \\
\text { Recode for composite } \\
\text { variable: } \\
1=\text { Low teacher's belief, if average point } \leq 2 \text {, } \\
2=\text { Medium teacher's belief, } \\
\text { if } 2<\text { average point }<4 \text { and } \\
3=\text { High teacher's belief, } \\
\text { if average point } \geq 4 .\end{array}$ \\
\hline $\begin{array}{c}\text { The academic } \\
\text { atmosphere at school } \\
\text { (perceived by the teacher) }\end{array}$ & $\begin{array}{l}\text { Composite variable based on how much does the student } \\
\text { agree with the following statements: } \\
\text { 1) Teachers are satisfied, } \\
\text { 2) Teachers understand the school's curricular goals, } \\
\text { 3) Teachers are successful in implementing the school's } \\
\text { curriculum, } \\
\text { 4) Teachers make the students achieve a good result, } \\
\text { 5) Parents support their child to achieve a good result, } \\
\text { 6) Parents involved in school activities, } \\
\text { 7) Students take care of their school property, } \\
\text { 8) Students are more conscious about their good results } \\
\text { at school and } \\
\text { 9) How the entire academic atmosphere of the school is. }\end{array}$ & $\begin{array}{l}\text { Initial code } \\
\text { (five-point Likert Scale): } \\
1=\text { very bad, } 2=\text { bad, } \\
3=\text { medium, } 4=\text { good, } \\
5 \text { = very good } \\
\text { Recode for composite variable: } \\
1=\text { Low academic atmosphere at school } \\
\text { if average point } \leq 2 \text {, } \\
2=\text { Med. academic atmosphere at school, } \\
\text { if } 2<\text { average point }<4 \\
3=\text { High academic atmosphere at school } \\
\text { if average point } \geq 4 .\end{array}$ \\
\hline School locality & $\begin{array}{l}\text { Single-item indicator } \\
\text { pointing the school locality }\end{array}$ & $\begin{array}{l}1=\text { Urban } \\
2=\text { Sub-urban, } \\
3=\text { Rural }\end{array}$ \\
\hline
\end{tabular}

